\title{
Higher Degree Committee Members' Perceptions of Quality Assurance of Doctoral Education: A South African Perspective
}

\author{
Petro du Preez \\ School for Education Studies \\ Faculty of Education Sciences, North-West University, \\ Potchefstroom Campus, South Africa \\ Shan Simmonds \\ Edu-HRight Research Unit
}

Petro.Dupreez@nwu.ac.za; Shan.Simmonds@nwu.ac.za

\section{Abstract}

In South Africa four key policy discourses underpin doctoral education: growth, capacity, efficiency, and quality discourses. This article contributes to the discourse on quality by engaging with quality assurance from the perspective of the decision makers and implementers of macro policy (national), meso (institutional), and micro (faculty/departmental) levels. We explore the perceptions that members of higher degree committees in the field of Education have of the quality assurance of doctoral education. Our data are drawn from a national survey questionnaire completed by these respondents at all public South African institutions that offer a doctorate in Education. The insights gained reside within four categories: positionality, policy, programmes, and people (stakeholders). Thereafter, we problematised the main results using academic freedom in a mode 3 knowledge production environment as a lens, which revealed thought provoking directions for future research about doctoral education.

Keywords: higher degree committee members, quality assurance, doctoral education, academic freedom, mode 3 knowledge production, higher education, South Africa

\section{Introduction}

Doctoral education in South Africa has been informed by four key policy discourses. Prominent amongst these are the growth discourse, capacity discourse, efficiency discourse, and quality discourse (Cloete, Mouton, \& Sheppard, 2015; Simmonds \& Du Preez, 2014). Growth discourse is concerned with the rapid increase in the number of doctoral candidates after 1994. Many students who were previously denied the right to equal opportunities as a result of discriminatory policies had the opportunity to do postgraduate study at any

(CC BY-NC 4.0) This article is licensed to you under a Creative Commons Attribution-

NonCommercial 4.0 International License. When you copy and redistribute this paper in full or in part, you need to provide proper attribution to it to ensure that others can later locate this work (and to ensure that others do not accuse you of plagiarism). You may (and we encourage you to) adapt, remix, transform, and build upon the material for any non-commercial purposes. This license does not permit you to use this material for commercial purposes. university. The rapid increase in numbers can therefore in part be ascribed to the changing sociopolitical context of the country at that time (Simmonds \& Du Preez, 2014, p. 1609). In addition to providing access, more recently the growth discourse is underpinned by production targets (Cloete et al., 2015, p. 21). The National Development Plan 2030 echoes these specific targets by advocating that if South Africa is to compete in the global knowledge economy 5000 doctoral graduates per 
annum must be produced (South Africa, 2011). Capacity discourse, which is closely related to growth discourse, problematises the ratio of staff qualified to offer supervision to new doctoral enrolments. A study revealed that only 33 per cent of academic staff at universities in 2007 held doctorates (Academy of Science for South Africa [ASSAf], 2010, p. 59). The limited capacity to supervise, coupled with the need to dramatically increase the number of doctoral graduates, has initiated a discourse on efficiency and quality assurance (Cloete et al., 2015, p. 17). The efficiency discourse further builds on the growth and capacity discourses as it emphasises that the production of doctoral candidates is often influenced by high drop-out and low completion rates. Empirical data has shown that in South Africa only $50 \%$ of doctoral enrolments successfully graduate (Cloete et al., 2015, p. 22; Department of Higher Education and Training [DHET], 2013). Some of the other primary challenges influencing the production of doctorates and their efficiency include the following: financial constraints; having to relearn basic research skills due to re-entry into higher education after a prolonged time; struggling with scientific writing/language skills/reading; lacking the skills to search for literature; unprepared (cannot cope or are overwhelmed) for the demands of doctoral study; and the inability to clearly conceptualise key concepts informing the topic being researched as well as the conceptualisation of the doctoral study as a whole (Cloete et al., 2015, p. 109, 138; Leshem \& Trafford, 2007, p. 102-103 ). The focus of quality discourse is on the quality of doctorates delivered, as opposed to the quantity of doctorates. Although interrelated with the other discourses, this discourse emphasises quality in terms of constituencies such as global competitiveness, international mobility, knowledge economy, and high-level research skills (Cloete, 2011). The importance of knowledge in economies is such a growing business because of its links into global information societies to foster innovation and development that it is being coined "the new electricity of the economy" (Cloete et al., 2015, p. 3). As a result, this discourse raises questions regarding quality assurance of doctoral education, not only in terms of input (policy, structure, monitoring, and reviewing) and output (doctoral degrees), but also in terms of processes. Issues related to the latter have yet to be explored in the Education discipline and this article aims to make a contribution to doing so.

A process-orientated approach to doctoral education requires an understanding of exactly what constitutes it. Doctoral education refers to the research training and curriculum that includes "a blend of knowledge, skills and dispositions that are typically learned through a relatively intense face-to-face pedagogical engagement between a novice and mature scholar/researcher (or two), sometimes supplemented by a research group comprising 'colleagues' with different levels of experience" (Grant, 2011, p. 246). Furthermore:

a doctoral curriculum differs significantly from any other in higher education because a core expectation is that new knowledge will be created by the student. Such a creative process is in its nature unpredictable and demanding: new knowledge does not emerge on command and, sometimes, when it does emerge it is not recognised as such. (Grant, 2011, p. 247)

Doctoral education of the traditional 'research only' thesis often includes processes related to supervision (Sinclair, 2004), proposal writing (Punch, 2006), thesis writing (Mouton, 2001), the assessment of a thesis (Tinkler \& Jackson, 2000) and the oral defence (Jackson \& Tinkler, 2001). In the Education discipline in South Africa there has been a tendency towards a traditional thesis comprised of research only in the form of an unpublished thesis. As a result, this study is framed within this form of thesis rather than the professional doctorate or thesis by publication which still needs to be better established in South Africa. Quality doctoral education has an important role to play in emphasising the importance of interrogating theory (new knowledge generation), context (knowledge applicable to the private or public sectors), and methodology (innovation) in one's discipline so they can make a significant contribution (Du Preez \& Simmonds, 2014). 
To contribute to theory, context and methodology resonates closely with theories of knowledge production. Mode 1 knowledge production is bound to autonomous, homogenous disciplines in which quality is determined and defined in peer review contexts (Hessels \& Van Lente, 2008, p. 741). In mode 1 knowledge production, the most important contribution that a doctoral candidate can make is on a theoretical level. Mode 2 knowledge production emphasises knowledge that is transferable and applicable to particular contexts (Hessels \& Van Lente, 2008, p. 741). This conception rests on a transdisciplinary, heterogeneous understanding of knowledge where novel methods of quality assurance of knowledge are related to reflexivity and social accountability (Hessels \& Van Lente, 2008, p. 741). The movement from mode 1 to 2 knowledge production is evident in the commercialisation of knowledge, the marketisation of higher education, and the increased focus on collaboration and globalisation (Hessels \& Van Lente, 2008, p. 742). Mode 3 knowledge production is described as a democratic approach to innovation: academics, government, industry, and civil society participate in knowledge production involving strategic development and decision-making based on feedback from all stakeholders that results in socially accountable policies and practices (Carayannis \& Campbell, 2012). Mode 3 knowledge production is dependent on human and intellectual capital that is shaped by social and financial capital to leverage higher order learning through bottom-up (entrepreneurship empowered) and top-down (policy development) initiatives (Carayannis \& Campbell, 2012). The movement towards modes 2 and 3 knowledge production necessitates that doctoral candidates do not only contribute to theory, but also to context and methodology. Contributing on all three levels, we argue, amounts to quality doctoral education.

Quality, however, is "a contested, multifaceted notion with a variety of meanings ... [an] illdefined problem that is under-theorised yet associated with high stakes policy-making and funding" (Krause, 2012, p. 285). Krause (2012) argues that discourses of quality - which are inevitably political - emanate from macro (national policies), meso (institutions), and micro (faculty/departmental level) contexts. In South Africa, the Higher Education Qualifications Committee (HEQC) is the macro level quality assurance body of higher education institutions (meso level) that regulates and monitors the quality of programmes by deciding which qualifications to accredit. The "link between quality and policy implementation at the institutional meso level, towards a growing interest in how academics respond to quality assurance and quality frameworks at the disciplinary and departmental level" (Krause, 2012, p. 288) still requires attention and further examination. We aim to address this issue by gaining deeper insights into higher degree committee members' perceptions of quality assurance of doctoral education. These members operate on the micro level (faculty/departmental level).

However, when engaging in quality assurance discourses, regulation of standards of doctoral programmes comes to the fore (Shaw \& Green, 2002, p. 116). Regulation is critiqued by some who argue that an over-emphasis on quality assurance procedures and imposing qualification frameworks pose threats to academic freedom and institutional autonomy (Bitzer, 2011, p. 34). From a similar stance, Collini (2012, p. 108) mounts a witty attack on those who over-emphasise quality assurance as if university staff needed to be constantly "checked up on" to keep idleness, incompetence and corruption at bay. This critique brings the notion of academic freedom to the table. Stone (2015, pp. 7-8) contends that our future concerns about academic freedom should include questions about money, silencing, fundamentalism, and neutrality. Cole (2015, pp. 40-41) argues that universities are increasingly dependent on external bodies, such as government, industry, business, and civil society, for income. This partly being a result of the move from mode 1 knowledge production to modes 2 and 3 knowledge production. One might argue that this dependence poses a serious threat to academic freedom; or one might take an alternative approach and argue that there lies a constructive contention between quality assurance as regulation and academic freedom. We have adopted the alternative approach towards the end of this article, 
when we argue that such constructive contention could be healthy in terms of both the improvement of quality assurance and the promotion of academic freedom.

\section{Research Design and Paradigmatic Position}

This article poses the following research questions: What is the state of higher degree committee members' perceptions of quality assurance of doctoral education at their respective universities? And, what hypothetical questions arise that could inform future research when the main results are problematised using academic freedom amidst mode 3 knowledge production as a lens? The research reported in this article forms part of a larger project funded by the South African National Research Foundation (NRF) entitled: Education research for quality doctoral study curriculum-making: a South African meta-study (2014-2016) (Du Preez, 2014). The purpose of this article is to contribute to discourses on quality assurance of doctoral education in the field of Education Studies. The data that are used were generated by descriptive and inferential statistical methodology within a positivist paradigm. This methodology allowed us to measure the responses, with due account taken of the relevant variables at a specific time, and without recourse to any form of manipulation (Maree \& Pietersen, 2007, p. 152).

\section{The Population}

The South African higher education landscape has changed since 2004 when colleges and technikons were integrated into the existing university structures or were merged to form new structures. (Historically, 'colleges' and 'technikons' were terms used in South Africa to describe institutions of higher and further education that offered practice-orientated qualifications that were fully aligned with employment demands.) In South Africa, there are three types of public universities: traditional universities, comprehensive universities, and universities of technology. Traditional universities offer "theoretically-orientated" degrees, whereas universities of technology (former colleges or technikons) offer "practice-orientated" diplomas and degrees (Beets, 2009, p. 187). Comprehensive universities offer a combination of these (Beets, 2009, p. 187). We wish to point out that traditional universities are not always research-driven and theoretically orientated institutions; continuous change in higher education contexts often results in changes in the foci of universities in this cluster. The same is true of the other clusters of universities. Hay and Marais (2011, p. 232) argue:

whether these typologies will have the desired outcome is debatable as there still seems to be an overlap and duplication in programme offerings and qualification structure as particular universities of technology are still struggling to claim their niches in the education market.

For the purpose of this research, we decided to retain these typologies to facilitate the analysis and comparison between the results.

A survey questionnaire was distributed to 20 (of the 23) public universities in South Africa that offer a doctoral degree in Education (PhD and DEd). Eleven were traditional universities (55\%), six comprehensive universities (30\%), and three universities of technology (15\%). One of the traditional universities did not take part in the research because internal transformation processes meant it was not possible for it to identify a list of respondents.

\section{The Sample}

The selected respondents are all from the Education discipline and serve on higher degrees committees at their respective institutions. These committees have a variety of names, such as master's and doctoral programme committees, master's and doctoral examination committees, faculty research committees, and departmental research committees. The respondents were chosen be- 
cause they are decision makers and implementers of macro (national) and meso (institutional) policy on the micro (faculty/departmental) level. Our statistical consultant advised us to obtain a minimum response rate of three respondents per institution to ensure a representative sample. The sample was therefore calculated prospectively with due consideration to the variables (types of universities in South Africa, higher degrees committee members) related to the sample (Houser, 2007, p. 1). Although we obtained only one respondent at one of the traditional universities, one at one of the comprehensive universities and two at one of the universities of technology, in our view this should not have a negative impact on the representativeness of the sample because up to 12 people per institution responded at the other institutions. It should be noted that at the three institutions where fewer than three respondents took part, the higher degrees committees had a smaller number of members than the others did. The survey was administered to a population of 240 people. A total of 80 respondents (33\%) completed the questionnaire: 50 respondents were employed at traditional universities $(62 \%), 18$ respondents at comprehensive universities $(23 \%)$, and 12 respondents at universities of technology $(15 \%)$. This relatively small number of respondents from each institution could be regarded as one of the weaknesses of this study. Tables 1-4 provide the following biographical information about the respondents: the number of years served on a higher degrees committee; the number of years involved in supervision, management, and education and; the number of doctoral candidates that they were currently supervising and that had obtained a doctorate under their supervision.

Table 1. Number of years served on a higher degrees committee

\begin{tabular}{llll}
\hline & $1-3$ years & $4-6$ years & $7+$ years \\
\hline Traditional University & 20 & 15 & 15 \\
& $(40 \%)$ & $(30 \%)$ & $(30 \%)$ \\
\hline Comprehensive University & 7 & 6 & 5 \\
& $(39 \%)$ & $(33 \%)$ & $(28 \%)$ \\
\hline University of Technology & 4 & 3 & 5 \\
& $(33 \%)$ & $(25 \%)$ & $(42 \%)$ \\
\hline Total sample 80 & & & \\
\hline
\end{tabular}

Table 2. Number of years involved with doctoral supervision / management / education

\begin{tabular}{llll}
\hline & $1-3$ years & $4-6$ years & $7+$ years \\
\hline Traditional University & 18 & 8 & 24 \\
& $(36 \%)$ & $(16 \%)$ & $(48 \%)$ \\
\hline Comprehensive University & 6 & 5 & 7 \\
& $(33 \%)$ & $(28 \%)$ & $(39 \%)$ \\
\hline University of Technology & 1 & 6 & 5 \\
& $(8 \%)$ & $(50 \%)$ & $(42 \%)$ \\
\hline Total sample 80 & & & \\
\hline
\end{tabular}

Table 3. Number of doctoral candidates currently being supervised or co-supervised

\begin{tabular}{lllll}
\hline & 0 & $1-5$ & $6-10$ & $11-20$ \\
\hline Traditional University & 6 & 32 & 6 & 6 \\
& $(12 \%)$ & $(64 \%)$ & $(12 \%)$ & $(12 \%)$ \\
\hline Comprehensive University & 0 & 13 & 4 & 1 \\
& $(0 \%)$ & $(72 \%)$ & $(22 \%)$ & $(6 \%)$ \\
\hline University of Technology & 4 & 7 & 1 & 0 \\
& $(33 \%)$ & $(58 \%)$ & $(8 \%)$ & $(0 \%)$ \\
\hline Total sample 80 & & & \\
\hline
\end{tabular}


Table 4. Number of doctoral candidates successfully supervised towards completion

\begin{tabular}{lllll}
\hline & 0 & $1-5$ & $6-10$ & $11-20$ \\
\hline Traditional University & 18 & 20 & 9 & 3 \\
& $(36 \%)$ & $(40 \%)$ & $(18 \%)$ & $(6 \%)$ \\
\hline Comprehensive University & 2 & 11 & 4 & 1 \\
& $(11 \%)$ & $(61 \%)$ & $(22 \%)$ & $(6 \%)$ \\
\hline University of Technology & 7 & 4 & 1 & 0 \\
& $(58 \%)$ & $(33 \%)$ & $(8 \%)$ & $(0 \%)$ \\
\hline Total sample 80 & & &
\end{tabular}

\section{The Survey Questionnaire}

The purpose of the survey questionnaire was to elicit higher degree committee members' perceptions of quality assurance of doctoral education, as well as to identify respondents' perceptions and knowledge. The questionnaire was developed by the researchers in collaboration with a statistical consultant. The items in this questionnaire were based on a report on the quality assurance in doctoral education in the European Union, which was entirely in line with the main questions of this study (Byrne, Jørgensen, \& Lukkola, 2013). The questionnaire was validated by experts on the research committee of our institution in terms of the phenomenon it set out to test (face validity) and its coverage of elements of the phenomenon (content validity) (Pietersen \& Maree, 2007, p. 217). Minor refinements to the questionnaire were made based on the expert feedback received. A pilot study was conducted amongst the research committee members to determine whether the instrument was adequate and appropriate prior to its distribution to the respondents (Bless, Higson-Smith, \& Sithole, 2013, p. 394).

The survey questionnaire was distributed via email with a link to SurveyMonkey after ethical clearance had been granted at the grant holder's institution and some of the other institutions that required ethical permission to conduct the research. A copy of the survey is included in this article as an Appendix. The respondents were first asked to provide biographical information. Thereafter, they were asked to complete the three main sections of the questionnaire. The items referred to the quality assurance in terms of doctoral education and degrees awarded in South Africa, doctoral proposal writing and the assessment of proposals, and the doctoral examination process. The questionnaire had a total of 30 Likert scale items and took less than 20 minutes to complete. The Likert scale had four levels: 1 (strongly disagree), 2 (disagree), 3 (agree) and 4 (strongly agree). This approach was followed to determine what respondents understanding, experience, knowledge and perceptions are based on their institutions.

\section{Statistical Data Analysis and Interpretation}

The responses were recorded in Excel and then analysed using descriptive statistics to arrive at broad indications of results. The main results have been clustered into four variables that inform quality assurance of doctoral education: positionality, policy, programmes, and people (stakeholders). These are presented in Tables 5-25 below. Thereafter further analysis by way of ANOVA and Kruskal-Wallis tests and a Spearman's rank order correlation was done to compare the variables.

\section{Positionality}

How respondents perceive positionality for quality assurance of doctoral education was prominent in the survey. The survey depicted this in three specific forms: firstly, international standing (Tables 5 and 6); secondly, national standing (Tables 7, 8, 9 and 10); and thirdly, standing within the broader realm in terms of scientific publications (Table 11), the community (Table 12) and the private sector (Table 13). 
The following statements asked by the survey pertained to international standing.

Table 5. Quality assurance of doctoral studies depends on the level of internationalisation at the institution

\begin{tabular}{lllllll}
\hline & $\begin{array}{l}\text { Strongly } \\
\text { Disagree }\end{array}$ & Disagree & Agree & $\begin{array}{l}\text { Strongly } \\
\text { Agree }\end{array}$ & $\begin{array}{l}\text { Total } \\
\text { Respondents }\end{array}$ & $\begin{array}{l}\text { Weighted } \\
\text { Average }\end{array}$ \\
\hline Traditional & 2 & 23 & 12 & 4 & 41 & 2.44 \\
& $5 \%$ & $56 \%$ & $29 \%$ & $10 \%$ & & \\
\hline Comprehensive & 1 & 6 & 5 & 1 & 13 & 2.46 \\
& $8 \%$ & $46 \%$ & $38 \%$ & $8 \%$ & & 2.58 \\
\hline University of Technology & 0 & 6 & 5 & 1 & 12 & \\
& $0 \%$ & $50 \%$ & $42 \%$ & $8 \%$ & & 66 \\
\hline Total answered & & & & & 14 & \\
\hline Missing responses & & & & & & \\
\hline
\end{tabular}

Table 6. The appointment of international examiners for the assessment of a doctoral dissertation / thesis contributes to the quality thereof

\begin{tabular}{lllllll}
\hline & $\begin{array}{l}\text { Strongly } \\
\text { disagree }\end{array}$ & Disagree & Agree & $\begin{array}{l}\text { Strongly } \\
\text { Agree }\end{array}$ & $\begin{array}{l}\text { Total } \\
\text { Respondents }\end{array}$ & $\begin{array}{l}\text { Weighted } \\
\text { Average }\end{array}$ \\
\hline Traditional & 1 & 11 & 18 & 10 & 40 & 2.92 \\
& $3 \%$ & $28 \%$ & $45 \%$ & $25 \%$ & & \\
\hline Comprehensive & 1 & 4 & 6 & 2 & 13 & 2.69 \\
& $8 \%$ & $31 \%$ & $46 \%$ & $15 \%$ & & 3.08 \\
\hline University of Technolo- & 0 & 2 & 7 & 3 & 12 & \\
gy & $0 \%$ & $17 \%$ & $58 \%$ & $25 \%$ & & 65 \\
\hline Total answered & & & & & 15 & \\
\hline Missing responses & & & & & \\
\hline
\end{tabular}

In terms of international standing, there was a difference in the respondents' stances on the level of internationalisation at their institution and their stance on appointing international examiners. In all cases, the latter was deemed more significant for quality assurance. More specifically, this was most true of respondents at universities of technology (10 agreed/strongly agreed, $83 \%$ ) and traditional universities (28 agreed/strongly agreed, $70 \%$ ), whilst the lowest level of agreement was at comprehensive universities (8 agreed/strongly agreed, $62 \%$ ) as represented in Table 6 . It seems that respondents at these institutions regard the appointment of international examiners as more of a factor in quality assurance than the level of internationalisation at their institutions.

The following statements asked by the survey pertained to national standing.

Table 7. Doctorates demonstrate high-level research that shifts the frontiers of their disciplines

\begin{tabular}{|c|c|c|c|c|c|c|}
\hline & $\begin{array}{l}\text { Strongly } \\
\text { disagree }\end{array}$ & Disagree & Agree & $\begin{array}{l}\text { Strongly } \\
\text { Agree }\end{array}$ & $\begin{array}{l}\text { Total Respond- } \\
\text { ents }\end{array}$ & $\begin{array}{l}\text { Weighted } \\
\text { Average }\end{array}$ \\
\hline Traditional & $\begin{array}{l}2 \\
65 \%\end{array}$ & $\begin{array}{l}6 \\
14 \%\end{array}$ & $\begin{array}{l}27 \\
63 \%\end{array}$ & $\begin{array}{l}8 \\
19 \%\end{array}$ & 43 & 2.95 \\
\hline Comprehensive & $\begin{array}{l}1 \\
7 \%\end{array}$ & $\begin{array}{l}4 \\
29 \% \\
\end{array}$ & $\begin{array}{l}8 \\
57 \%\end{array}$ & $\begin{array}{l}1 \\
7 \%\end{array}$ & 14 & 2.64 \\
\hline $\begin{array}{l}\text { University of Technol- } \\
\text { ogy }\end{array}$ & $\begin{array}{l}0 \\
0 \% \\
\end{array}$ & $\begin{array}{l}4 \\
33 \% \\
\end{array}$ & $\begin{array}{l}8 \\
67 \% \\
\end{array}$ & $\begin{array}{l}0 \\
0 \%\end{array}$ & 12 & 2.67 \\
\hline Total answered & & & & & 69 & \\
\hline Missing responses & & & & & 11 & \\
\hline
\end{tabular}


Table 8. Quality assurance of doctoral studies depends on the quality of supervision provided

\begin{tabular}{lllllll}
\hline & $\begin{array}{l}\text { Strongly } \\
\text { disagree }\end{array}$ & Disagree & Agree & $\begin{array}{l}\text { Strongly } \\
\text { Agree }\end{array}$ & $\begin{array}{l}\text { Total Respond- } \\
\text { ents }\end{array}$ & $\begin{array}{l}\text { Weighted } \\
\text { Average }\end{array}$ \\
\hline Traditional & 0 & 1 & 15 & 23 & 39 & 3.56 \\
& $0 \%$ & $2 \%$ & $38 \%$ & $59 \%$ & & 3.64 \\
\hline Comprehensive & 0 & 0 & 5 & 9 & 14 & 3 \\
& $0 \%$ & $0 \%$ & $36 \%$ & $64 \%$ & & \\
\hline University of Technol- & 0 & 4 & 4 & 4 & 12 & \\
ogy & $0 \%$ & $33 \%$ & $33 \%$ & $33 \%$ & & 65 \\
\hline Total answered & & & & & 15 & \\
\hline Missing responses & & & & &
\end{tabular}

Table 9. The quality of the doctorate awarded depends on the reputation of the awarding institution

\begin{tabular}{lllllll}
\hline & $\begin{array}{l}\text { Strongly } \\
\text { disagree }\end{array}$ & Disagree & Agree & $\begin{array}{l}\text { Strongly } \\
\text { Agree }\end{array}$ & $\begin{array}{l}\text { Total Respond- } \\
\text { ents }\end{array}$ & $\begin{array}{l}\text { Weighted } \\
\text { Average }\end{array}$ \\
\hline Traditional & 4 & 13 & 12 & 11 & 40 & 2.75 \\
& $10 \%$ & $33 \%$ & $30 \%$ & $28 \%$ & & 2.62 \\
\hline Comprehensive & 1 & 5 & 5 & 2 & 13 & 2.42 \\
& $8 \%$ & $39 \%$ & $38 \%$ & $15 \%$ & & \\
\hline University of Technol- & 2 & 5 & 3 & 2 & 14 & \\
ogy & $17 \%$ & $42 \%$ & $25 \%$ & $17 \%$ & & 67 \\
\hline Total answered & & & & & 13 & \\
\hline Missing responses & & & & & & \\
\hline
\end{tabular}

Table 10. The quality of the doctorate awarded depends on the examiners appointed to assess the thesis / dissertation

\begin{tabular}{lllllll}
\hline & $\begin{array}{l}\text { Strongly } \\
\text { disagree }\end{array}$ & Disagree & Agree & $\begin{array}{l}\text { Strongly } \\
\text { Agree }\end{array}$ & $\begin{array}{l}\text { Total Respond- } \\
\text { ents }\end{array}$ & $\begin{array}{l}\text { Weighted } \\
\text { Average }\end{array}$ \\
\hline Traditional & 0 & 9 & 18 & 13 & 40 & 3.10 \\
& $0 \%$ & $23 \%$ & $45 \%$ & $33 \%$ & & 2.38 \\
\hline Comprehensive & 1 & 7 & 4 & 1 & 13 & 2.42 \\
& $8 \%$ & $54 \%$ & $31 \%$ & $8 \%$ & & \\
\hline University of Technol- & 2 & 5 & 3 & 2 & 12 & \\
ogy & $17 \%$ & $42 \%$ & $25 \%$ & $17 \%$ & & 65 \\
\hline Total answered & & & & & 15 & \\
\hline Missing responses & & & & & \\
\hline
\end{tabular}

From the responses, it is evident that the overall ranking of levels of national positionality was first quality assurance through the supervision provided (Table 8), second, shifting the frontiers of the discipline (Table 7), thirdly the examiners appointed (Table 10), and lastly the reputation of the university (Table 9).

In Table 8 the respondents at comprehensive universities expressed $100 \%$ agreement that the quality of supervision provided is the most important, whilst 31 respondents (97\%) at traditional universities and five $(66 \%)$ at universities of technology agreed/strongly agreed. Significantly, the respondents at universities of technology who agreed with this statement were $30 \%$ less than the other institutions. With regard to shifting the frontiers of the discipline, Table 7 displays that 35 of the respondents $(82 \%)$ at traditional universities perceived their doctorates as demonstrating the required high-level research. Respondents at comprehensive universities and universities of technology recorded a much lower level of support, only $9(64 \%)$ and $8(67 \%)$ respondents respectively. 
With regard to the other aspects, examiners appointed and the institution's reputation, the levels of agreement were lower. As represented in Table 10, 31 respondents (78\%) at traditional universities were most strongly in agreement that the examiners appointed would influence the quality of the doctorate awarded. The level of agreement of universities of technology and comprehensive universities was much lower: $5(42 \%)$ and $5(38 \%)$, respectively. In respect of the reputation of the institution awarding the doctorate, Table 9 shows that 23 respondents $(58 \%)$ at traditional universities and comprehensive universities 7 respondents (53\%) showed the greatest level of support, as opposed to universities of technology 5 respondents $(42 \%)$.

The following statements asked by the survey concerned standing within the broader realm in terms of scientific publications (Table 11), the community (Table 12), and the private sector (Table 13).

Table 11. The quality of the doctorate awarded

depends on the scientific publications that arose from the research

\begin{tabular}{lllllll}
\hline & $\begin{array}{l}\text { Strongly } \\
\text { disagree }\end{array}$ & Disagree & Agree & $\begin{array}{l}\text { Strongly } \\
\text { Agree }\end{array}$ & $\begin{array}{l}\text { Total Respond- } \\
\text { ents }\end{array}$ & $\begin{array}{l}\text { Weighted } \\
\text { Average }\end{array}$ \\
\hline Traditional & 0 & 16 & 18 & 8 & 42 & 2.81 \\
& $0 \%$ & $38 \%$ & $43 \%$ & $19 \%$ & & 2.57 \\
\hline Comprehensive & 2 & 5 & 4 & 3 & 14 & 2.75 \\
& $14 \%$ & $36 \%$ & $29 \%$ & $22 \%$ & & 12 \\
\hline University of Technol- & 1 & 3 & 6 & 2 & & \\
ogy & $8 \%$ & $25 \%$ & $50 \%$ & $17 \%$ & & 12 \\
\hline Total answered & & & & &
\end{tabular}

Table 12. The quality of the doctorate awarded depends on the impact of the research on the community

\begin{tabular}{lllllll}
\hline & $\begin{array}{l}\text { Strongly } \\
\text { disagree }\end{array}$ & Disagree & Agree & $\begin{array}{l}\text { Strongly } \\
\text { Agree }\end{array}$ & $\begin{array}{l}\text { Total Respond- } \\
\text { ents }\end{array}$ & $\begin{array}{l}\text { Weighted } \\
\text { Average }\end{array}$ \\
\hline Traditional & 0 & 13 & 23 & 5 & 41 & 2.8 \\
& $0 \%$ & $32 \%$ & $56 \%$ & $12 \%$ & & 2.86 \\
\hline Comprehensive & 1 & 2 & 9 & 2 & 14 & 2.67 \\
& $7 \%$ & $14 \%$ & $64 \%$ & $14 \%$ & & \\
\hline University of Technol- & 1 & 3 & 7 & 1 & 12 & \\
ogy & $8 \%$ & $25 \%$ & $58 \%$ & $8 \%$ & & 67 \\
\hline Total answered & & & & & 13 & \\
\hline Missing responses & & & & & & \\
\hline
\end{tabular}

Table 13. The quality of the doctorate awarded

depends on the extent to which it contributed to innovation in the private sector

\begin{tabular}{|c|c|c|c|c|c|c|}
\hline & $\begin{array}{l}\text { Strongly } \\
\text { disagree }\end{array}$ & Disagree & Agree & $\begin{array}{l}\text { Strongly } \\
\text { Agree }\end{array}$ & $\begin{array}{l}\text { Total Respond- } \\
\text { ents }\end{array}$ & $\begin{array}{l}\text { Weighted } \\
\text { Average }\end{array}$ \\
\hline Traditional & $\begin{array}{l}7 \\
17 \%\end{array}$ & $\begin{array}{l}24 \\
58 \%\end{array}$ & $\begin{array}{l}7 \\
17 \%\end{array}$ & $\begin{array}{l}3 \\
7 \%\end{array}$ & 41 & 2.15 \\
\hline Comprehensive & $\begin{array}{l}2 \\
15 \%\end{array}$ & $\begin{array}{l}6 \\
46 \%\end{array}$ & $\begin{array}{l}5 \\
38 \%\end{array}$ & $\begin{array}{l}0 \\
0 \%\end{array}$ & 13 & 2.23 \\
\hline $\begin{array}{l}\text { University of Technol- } \\
\text { ogy }\end{array}$ & $\begin{array}{l}0 \\
0 \%\end{array}$ & $\begin{array}{l}6 \\
50 \% \\
\end{array}$ & $\begin{array}{l}5 \\
42 \%\end{array}$ & $\begin{array}{l}1 \\
8 \%\end{array}$ & 12 & 2.58 \\
\hline Total answered & & & & & 66 & \\
\hline Missing responses & & & & & 14 & \\
\hline
\end{tabular}


As is evident in Tables 11, 12, and 13, it seems that most respondents ( 8 at universities of technology, 28 at traditional universities, and 11 at comprehensive universities) see the impact and contribution they make in the community as a measure of the quality of the doctorates currently awarded at their institutions (see Table 12). The realm that received the second most overall support was the impact and contribution made by doctorates through scientific publications as represented by Table 11 ( 7 of respondents at comprehensive universities, 26 at traditional universities, and 8 at universities of technology). Table 13 illustrates that the lowest level of overall support was the contribution of doctorates through innovation in the private sector. Only 10 respondents $(24 \%)$ at traditional universities, 5 respondents $(38 \%)$ at comprehensive universities, and 6 respondents $(50 \%)$ at universities of technology agreed with the statement.

\section{Policy}

Respondents' perceptions of policy are developed and implemented on varying levels towards quality assurance of doctoral education. The survey depicted this through the following 7 statements (Tables 14-20). Tables 14 and 15 provide an indication of the respondents' perceptions of quality assurance on macro (national) and micro (institutional) policy levels. For Tables 16 and 17 the focus is on policy at a meso (institutional) level so as to determine the state of quality assurance and promoting a culture of quality assurance at their institutions. To conclude this section, respondents' perceptions of quality assurance on a micro (faculty/departmental) level were shared in terms of the criteria for assessing doctoral candidates' proposals for their potential methodological (Table 18), theoretical (Table 19) and contextual (Table 20) contributions.

\section{Table 14. Accreditation of doctoral qualifications} by the Higher Education Qualifications Committee assures quality

\begin{tabular}{lllllll}
\hline & $\begin{array}{l}\text { Strongly } \\
\text { disagree }\end{array}$ & Disagree & Agree & $\begin{array}{l}\text { Strongly } \\
\text { Agree }\end{array}$ & $\begin{array}{l}\text { Total Re- } \\
\text { spondents }\end{array}$ & $\begin{array}{l}\text { Weighted } \\
\text { Average }\end{array}$ \\
\hline Traditional & 0 & 9 & 22 & 12 & 43 & 3.07 \\
& $0 \%$ & $21 \%$ & $51 \%$ & $28 \%$ & & \\
\hline Comprehensive & 1 & 2 & 10 & 1 & 14 & 2.79 \\
& $7 \%$ & $14 \%$ & $71 \%$ & $7 \%$ & & 2.75 \\
\hline University of Technol- & 0 & 3 & 9 & 0 & 12 & \\
ogy & $0 \%$ & $25 \%$ & $75 \%$ & $0 \%$ & & 69 \\
\hline Total answered & & & & & 11 & \\
\hline Missing responses & & & & &
\end{tabular}

Table 15. Quality assurance on the doctoral level is a matter of institutional accountability

\begin{tabular}{llllllc}
\hline & $\begin{array}{l}\text { Strongly } \\
\text { disagree }\end{array}$ & Disagree & Agree & $\begin{array}{l}\text { Strongly } \\
\text { Agree }\end{array}$ & $\begin{array}{l}\text { Total Re- } \\
\text { spondents }\end{array}$ & $\begin{array}{l}\text { Weighted } \\
\text { Average }\end{array}$ \\
\hline Traditional & 1 & 1 & 22 & 17 & 41 & 3.34 \\
& $2 \%$ & $2 \%$ & $54 \%$ & $41 \%$ & & 3.14 \\
\hline Comprehensive & 0 & 1 & 10 & 3 & 14 & 2.73 \\
& $0 \%$ & $7 \%$ & $72 \%$ & $21 \%$ & & \\
\hline University of Technol- & 1 & 2 & 7 & 1 & 11 & \\
ogy & $9 \%$ & $18 \%$ & $64 \%$ & $9 \%$ & & 66 \\
\hline Total answered & & & & & 14 & \\
\hline Missing responses & & & & & & \\
\hline
\end{tabular}

Tables 14 and 15 depict macro (national) and meso (institutional) perceptions on policy for quality assurance of doctoral education. From Table 15 it is evident that respondents at traditional and comprehensive universities regard quality assurance as more a matter of institutional accountability than national accreditation. Their scores for institutional accountability were $95 \%$ (39 respondents) and 93\% (13 respondents), respectively, as compared with Table 14 that shows their 
support for the view that the national HEQC accreditation of doctoral qualifications assures quality (79\% [34 respondents] and 78\% [11 respondents], respectively). Therefore, for these respondents quality assurance is situated on the meso level (institutional) rather than on the macro level (national). For universities of technology however, similar importance is placed on national HEQC accreditation of doctoral qualifications (9 respondents, 75\%, Table 14) and institutional accountability ( 8 respondents, $73 \%$, Table 15 ) to assure quality at their institutions.

Tables 16-17 infer the perceptions that respondents hold of meso or institutional policy with regard to quality assurance at their institution (Table 16) and their institution promoting a quality culture (Table 17).

Table 16. Quality assurance on the doctoral level is aimed to improve the quality of doctoral education

\begin{tabular}{lllllll}
\hline & $\begin{array}{l}\text { Strongly } \\
\text { disagree }\end{array}$ & Disagree & Agree & $\begin{array}{l}\text { Strongly } \\
\text { Agree }\end{array}$ & $\begin{array}{l}\text { Total Respond- } \\
\text { ents }\end{array}$ & $\begin{array}{l}\text { Weighted } \\
\text { Average }\end{array}$ \\
\hline Traditional & 0 & 6 & 22 & 13 & 41 & 3.17 \\
& $0 \%$ & $15 \%$ & $54 \%$ & $32 \%$ & & 3.2 \\
\hline Comprehensive & 0 & 1 & 10 & 4 & 15 & 3.08 \\
& $0 \%$ & $7 \%$ & $67 \%$ & $27 \%$ & & \\
\hline University of Technol- & 0 & 0 & 11 & 1 & 12 & \\
ogy & $0 \%$ & $0 \%$ & $92 \%$ & $8 \%$ & & 68 \\
\hline Total answered & & & & & 12 & \\
\hline Missing responses & & & & & \\
\hline
\end{tabular}

Table 17. Universities promote a 'quality culture' regarding doctoral education rather than simply putting quality assurance processes in place

\begin{tabular}{|c|c|c|c|c|c|c|}
\hline & $\begin{array}{l}\text { Strongly } \\
\text { disagree }\end{array}$ & Disagree & Agree & $\begin{array}{l}\text { Strongly } \\
\text { Agree }\end{array}$ & $\begin{array}{l}\text { Total Respond- } \\
\text { ents }\end{array}$ & $\begin{array}{l}\text { Weighted } \\
\text { Average }\end{array}$ \\
\hline \multirow[t]{2}{*}{ Traditional } & 1 & 13 & 15 & 12 & 41 & 2.93 \\
\hline & $2 \%$ & $32 \%$ & $37 \%$ & $29 \%$ & & \\
\hline Comprehensive & $\begin{array}{l}0 \\
0 \%\end{array}$ & $\begin{array}{l}4 \\
29 \%\end{array}$ & $\begin{array}{l}9 \\
64 \%\end{array}$ & $\begin{array}{l}1 \\
7 \%\end{array}$ & 14 & 2.79 \\
\hline $\begin{array}{l}\text { University of Technol- } \\
\text { ogy }\end{array}$ & $\begin{array}{l}0 \\
0 \% \\
\end{array}$ & $\begin{array}{l}5 \\
42 \% \\
\end{array}$ & $\begin{array}{l}6 \\
50 \% \\
\end{array}$ & $\begin{array}{l}1 \\
8 \% \\
\end{array}$ & 12 & 2.67 \\
\hline Total answered & & & & & 67 & \\
\hline Missing responses & & & & & 13 & \\
\hline
\end{tabular}

The vast majority of the respondents agreed that quality assurance on the doctoral level is aimed at improving the level of doctoral education (see Table 16): 12 respondents (100\%) at universities of technology, 14 respondents (94\%) at comprehensive universities, and 35 respondents (86\%) at traditional universities. However, as depicted by Table 17, fewer of them believed that their institutions promoted a 'quality culture' rather than simply putting quality assurance processes in place. There was about $20 \%$ less agreement by respondents at traditional and comprehensive universities, $27(66 \%)$ and 10 respondents (71\%) respectively. There was a dramatic difference in the level of agreement of respondents at universities of technology: 7 respondents $(58 \%)$ as opposed to 12 respondents $(100 \%)$.

In terms of micro (faculty/departmental) policy, respondents shared their perceptions of quality assurance based on the criteria for assessing proposals (Tables 18-20). 
Table 18. Proposals are assessed by a committee to determine whether a potential methodological contribution will be made in the study

\begin{tabular}{llllllc}
\hline & $\begin{array}{l}\text { Strongly } \\
\text { disagree }\end{array}$ & Disagree & Agree & $\begin{array}{l}\text { Strongly } \\
\text { Agree }\end{array}$ & $\begin{array}{l}\text { Total Respond- } \\
\text { ents }\end{array}$ & $\begin{array}{l}\text { Weighted } \\
\text { Average }\end{array}$ \\
\hline Traditional & 0 & 5 & 19 & 17 & 41 & 3.29 \\
& $0 \%$ & $12 \%$ & $46 \%$ & $41 \%$ & & 3.08 \\
\hline Comprehensive & 0 & 4 & 4 & 5 & 13 & 3.08 \\
& $0 \%$ & $31 \%$ & $31 \%$ & $38 \%$ & & \\
\hline University of Technol- & 0 & 3 & 5 & 4 & 12 & \\
ogy & $0 \%$ & $25 \%$ & $42 \%$ & $33 \%$ & & 66 \\
\hline Total answered & & & & & 14 & \\
\hline Missing responses & & & & &
\end{tabular}

Table 19. Proposals are assessed by a committee to determine whether a potential theoretical contribution will be made in the study

\begin{tabular}{llllllc}
\hline & $\begin{array}{l}\text { Strongly } \\
\text { disagree }\end{array}$ & Disagree & Agree & $\begin{array}{l}\text { Strongly } \\
\text { Agree }\end{array}$ & $\begin{array}{l}\text { Total Respond- } \\
\text { ents }\end{array}$ & $\begin{array}{l}\text { Weighted } \\
\text { Average }\end{array}$ \\
\hline Traditional & 0 & 4 & 18 & 19 & 41 & 3.37 \\
& $0 \%$ & $10 \%$ & $44 \%$ & $46 \%$ & & 3.23 \\
\hline Comprehensive & 0 & 2 & 6 & 5 & 13 & 3.33 \\
& $0 \%$ & $15 \%$ & $46 \%$ & $38 \%$ & & \\
\hline University of Technol- & 0 & 0 & 8 & 4 & 12 & \\
ogy & $0 \%$ & $0 \%$ & $67 \%$ & $33 \%$ & & 66 \\
\hline Total answered & & & & & 14 & \\
\hline Missing responses & & & & & & \\
\hline
\end{tabular}

Table 20. Proposals are assessed by a committee to determine whether a potential contextual contribution will be made through the study

\begin{tabular}{lllllll}
\hline & $\begin{array}{l}\text { Strongly } \\
\text { disagree }\end{array}$ & Disagree & Agree & $\begin{array}{l}\text { Strongly } \\
\text { Agree }\end{array}$ & $\begin{array}{l}\text { Total Respond- } \\
\text { ents }\end{array}$ & $\begin{array}{l}\text { Weighted } \\
\text { Average }\end{array}$ \\
\hline Traditional & 0 & 4 & 22 & 14 & 40 & 3.25 \\
& $0 \%$ & $10 \%$ & $55 \%$ & $35 \%$ & & 3.08 \\
\hline Comprehensive & 0 & 2 & 8 & 3 & 13 & 3 \\
& $0 \%$ & $15 \%$ & $62 \%$ & $23 \%$ & & \\
\hline University of Technol- & 0 & 2 & 8 & 2 & 12 & \\
ogy & $0 \%$ & $17 \%$ & $67 \%$ & $17 \%$ & & 65 \\
\hline Total answered & & & & & 15 & \\
\hline Missing responses & & & & & \\
\hline
\end{tabular}

All the respondents agreed/strongly agreed that assessing doctoral proposals on their potential theoretical, contextual, and methodological contribution to the discipline leads to quality assurance. However, the highest percentage agreement at all three types of universities was for proposals to be assessed on their potential theoretical contribution. As displayed by Table 19, all 12 of the respondents at universities of technology (100\%), 37 respondents $(90 \%)$ at traditional universities, and 11 respondents (84\%) at comprehensive universities agreed/strongly agreed. Assessing proposals for their potential contextual contribution received the second highest overall level of agreement: 36 of the respondents $(90 \%)$ at traditional universities, 11 respondents $(85 \%)$ at comprehensive universities, and 10 respondents (84\%) at universities of technology (see Table 20). The lowest level of overall agreement was with the statement that doctoral candidates' proposals should be assessed on their potential methodological contribution. On Table 18 the figures were 9 respondents at comprehensive universities (69\%), 9 respondents at universities of technology $(75 \%)$, and 36 respondents at traditional universities $(87 \%)$. 
What is worth noting is that respondents at traditional universities were the only ones who considered that all three contributions (theoretical, contextual, and methodological) were very important; there was very little variance $(90 \%, 90 \%$ and $87 \%)$.

\section{Programmes}

Respondents were asked to provide their perceptions regarding doctoral education programmes in proposal and examination processes at their institutions and what this entailed for quality assurance of doctoral education. Two survey questions captured this; Table 21 alludes to the formal training in proposal writing and Table 22 to the formal training at the examination stage.

Table 21. Formal training of doctoral candidates in proposal writing assists in the overall quality of a study

\begin{tabular}{lllllll}
\hline & $\begin{array}{l}\text { Strongly } \\
\text { disagree }\end{array}$ & Disagree & Agree & $\begin{array}{l}\text { Strongly } \\
\text { Agree }\end{array}$ & $\begin{array}{l}\text { Total Re- } \\
\text { spondents }\end{array}$ & $\begin{array}{l}\text { Weighted } \\
\text { Average }\end{array}$ \\
\hline Traditional & 0 & 2 & 23 & 16 & 41 & 3.34 \\
& $0 \%$ & $5 \%$ & $56 \%$ & $39 \%$ & & 3.31 \\
\hline Comprehensive & 0 & 0 & 9 & 4 & 13 & 3.08 \\
& $0 \%$ & $0 \%$ & $69 \%$ & $31 \%$ & & \\
\hline University of Technol- & 0 & 2 & 7 & 3 & 12 & \\
ogy & $0 \%$ & $17 \%$ & $58 \%$ & $25 \%$ & & 66 \\
\hline Total answered & & & & & 14 & \\
\hline Missing responses & & & & & \\
\hline
\end{tabular}

Table 22. Doctoral candidates receive formal training to prepare them for the examination process

\begin{tabular}{lllllll}
\hline & $\begin{array}{l}\text { Strongly } \\
\text { disagree }\end{array}$ & Disagree & Agree & $\begin{array}{l}\text { Strongly } \\
\text { Agree }\end{array}$ & $\begin{array}{l}\text { Total Re- } \\
\text { spondents }\end{array}$ & $\begin{array}{l}\text { Weighted } \\
\text { Average }\end{array}$ \\
\hline Traditional & 1 & 22 & 11 & 4 & 38 & 2.47 \\
& $3 \%$ & $58 \%$ & $29 \%$ & $11 \%$ & & \\
\hline Comprehensive & 2 & 5 & 5 & 0 & 12 & 2.25 \\
& $17 \%$ & $42 \%$ & $42 \%$ & $0 \%$ & & \\
\hline $\begin{array}{l}\text { University of Technol- } \\
\text { ogy }\end{array}$ & 1 & 7 & 3 & 1 & 12 & 2.33 \\
& $8 \%$ & $58 \%$ & $25 \%$ & $8 \%$ & & \\
\hline Total answered & & & & & 62 & \\
\hline Missing responses & & & & & & \\
\hline
\end{tabular}

It was evident in Table 21 that a high percentage of respondents supported the view that programmes in proposal writing offered to doctoral candidates at their institutions assist in quality assurance. All 13 of the respondents at comprehensive universities (100\%) agreed/strongly agreed that these programmes assisted in assuring quality. The level of agreement at traditional universities and universities of technology was 39 respondents (95\%) and 13 respondents (83\%), respectively.

It seems that, although institutions seem to provide doctoral candidates with satisfactory education programmes to write their proposals, this is significantly less the case in the examination phase. From Table 22 it is evident that the level of agreement at traditional universities was 15 respondents $(40 \%)$, comprehensive universities 5 respondents $(42 \%)$, and universities of technology 4 respondents $(33 \%)$. 


\section{People (stakeholders)}

The people (stakeholders) involved in doctoral education also contribute to how quality is assured. The survey gained respondents perceptions in terms of the supervisor (Table 23), candidate (Table 24) and examiner (Table 25) to depict this variable.

Table 23. The quality of the doctorate awarded depends on the disciplinary knowledge of a supervisor

\begin{tabular}{lllllll}
\hline & $\begin{array}{l}\text { Strongly } \\
\text { disagree }\end{array}$ & Disagree & Agree & $\begin{array}{l}\text { Strongly } \\
\text { Agree }\end{array}$ & $\begin{array}{l}\text { Total Respond- } \\
\text { ents }\end{array}$ & $\begin{array}{l}\text { Weighted } \\
\text { Average }\end{array}$ \\
\hline Traditional & 0 & 7 & 20 & 14 & 41 & 3.17 \\
& $0 \%$ & $17 \%$ & $49 \%$ & $34 \%$ & & 3.14 \\
\hline Comprehensive & 0 & 2 & 8 & 4 & 14 & 2.91 \\
& $0 \%$ & $14 \%$ & $57 \%$ & $29 \%$ & & \\
\hline University of Technol- & 0 & 3 & 6 & 2 & 11 & \\
ogy & $0 \%$ & $27 \%$ & $55 \%$ & $18 \%$ & & 66 \\
\hline Total answered & & & & & 14 & \\
\hline Missing responses & & & & &
\end{tabular}

Table 24. The quality of the doctorate awarded depends on the candidate's engagement with the study

\begin{tabular}{lllllll}
\hline & $\begin{array}{l}\text { Strongly } \\
\text { disagree }\end{array}$ & Disagree & Agree & $\begin{array}{l}\text { Strongly } \\
\text { Agree }\end{array}$ & $\begin{array}{l}\text { Total Respond- } \\
\text { ents }\end{array}$ & $\begin{array}{l}\text { Weighted } \\
\text { Average }\end{array}$ \\
\hline Traditional & 0 & 1 & 12 & 28 & 41 & 3.66 \\
& $0 \%$ & $2 \%$ & $29 \%$ & $68 \%$ & & 3.64 \\
\hline Comprehensive & 0 & 0 & 5 & 9 & 14 & 3.55 \\
& $0 \%$ & $0 \%$ & $36 \%$ & $64 \%$ & & \\
\hline University of Technol- & 0 & 0 & 5 & 6 & 11 & \\
ogy & $0 \%$ & $0 \%$ & $45 \%$ & $55 \%$ & & 66 \\
\hline Total answered & & & & & 14 & \\
\hline Missing responses & & & & &
\end{tabular}

Table 25. The quality of the doctorate awarded depends on the examiners appointed to assess the thesis / dissertation

\begin{tabular}{lllllll}
\hline & $\begin{array}{l}\text { Strongly } \\
\text { disagree }\end{array}$ & Disagree & Agree & $\begin{array}{l}\text { Strongly } \\
\text { Agree }\end{array}$ & $\begin{array}{l}\text { Total Respond- } \\
\text { ents }\end{array}$ & $\begin{array}{l}\text { Weighted } \\
\text { Average }\end{array}$ \\
\hline Traditional & 0 & 9 & 18 & 13 & 40 & 3.10 \\
& $0 \%$ & $23 \%$ & $45 \%$ & $33 \%$ & & 2.38 \\
\hline Comprehensive & 1 & 7 & 4 & 1 & 13 & 2.42 \\
& $8 \%$ & $54 \%$ & $31 \%$ & $8 \%$ & & \\
\hline University of Technol- & 2 & 5 & 3 & 2 & 12 & \\
ogy & $17 \%$ & $42 \%$ & $25 \%$ & $17 \%$ & & 65 \\
\hline Total answered & & & & & 15 & \\
\hline Missing responses & & & & & \\
\hline
\end{tabular}

It seems that the stakeholders involved in the doctoral study are perceived as having an impact on the quality of the doctorate. As can be seen from Table 24, the strongest support was for candidates' engagement with their study: 40 respondents (97\%) at traditional universities, 14 respondents $(100 \%)$ at comprehensive universities, and 11 respondents $(100 \%)$ at universities of technology. Table 23 illustrates that a very high number of the respondents at comprehensive (12 respondents, $86 \%$ ) and traditional (34 respondents, $83 \%$ ) universities agreed/strongly agreed that the supervisor's disciplinary knowledge was a factor in assuring quality. Although still high, the level of agreement at universities of technology was lower ( 8 respondents, $73 \%$ ). However, the 
examiner appointed to assess the thesis/dissertation did not attract as much support (see Table 25). This was especially true in the case of the respondents at comprehensive universities and universities of technology. Only 5 respondents at each institution agreed/strongly agreed that the appointment of examiners contributed to quality assurance. Although a larger percentage of respondents at traditional universities (31 respondents, $78 \%$ ) agreed that the examiner appointed to assess the thesis/dissertation is an important element to assure quality.

\section{Comparison of variables (positionality, policy, programmes, and people)}

A Cronbach coefficient alpha calculation was done to determine the internal consistency between the survey items making up each of the four variables (positionality, policy, programmes, and people) that emerged in the results. As indicated on Table 26, factor scores could be calculated for 'positionality' (Tables 5-13) and 'policy' (Tables 14-20) because they had sufficient reliability. 'Programmes' (Tables 21-22) and 'people' (Tables 23-25) did not have sufficient reliability to compute scores. Therefore they were analysed and discussed as separate items.

Table 26. Cronbach coefficient alpha and descriptive statistics of latent variables

\begin{tabular}{llrc}
\hline & $\begin{array}{l}\text { Cronbach } \\
\text { coefficient alpha }\end{array}$ & Mean & $\begin{array}{l}\text { Std. } \\
\text { Deviation }\end{array}$ \\
\hline Positionality (Tables 5-13) & .787 & 2.79 & .417 \\
\hline Policy (Tables 14-20) & .664 & 3.14 & .452 \\
\hline Programme (Table 21-22) & .461 & - & - \\
\hline People (Table 23-25) & .461 & - & - \\
\hline
\end{tabular}

Two analyses were done to determine comparisons between the four variables (positionaility, policy, programmes, and people) and the demographics and biographics of the respondents. One analysis compared the four variables with the three clusters of universities (traditional, comprehensive, and universities of technology). The second analysis made a comparison between the four variables and the biographical make-up of the participants. With the statistical significance set at 0.05 , the following results became evident.

In the first analysis ANOVA and Kruskal-Wallis tests were performed. The results are presented in Table 27. The results indicate that the only statistically significant difference was found for the item: 'The quality of the doctorate depends on the examiners appointed to assess the thesis/dissertation' (indicated on Table 27 as People: Examiner). Dunn's non-parametric multiple comparisons indicated that traditional universities agree more than comprehensive universities on this item $(\mathrm{p}=0.039)$. No statistical significance was detected for the other items. 
Table 27. Results of ANOVA and Kruskal-Wallis tests

\begin{tabular}{lcccccc}
\hline & \multicolumn{3}{c}{ Means of universities } & \multicolumn{3}{c}{ ANOVA } \\
\hline & Traditional & Comprehensive & Technology & MSE & p-value & $\begin{array}{l}\text { Kruskal- } \\
\text { Wallis } \\
\text { p-value }\end{array}$ \\
\hline $\begin{array}{l}\text { Positionality (Ta- } \\
\text { bles 5-13) }\end{array}$ & 2.8461 & 2.7185 & 2.6852 & .17 & .378 & .531 \\
\hline $\begin{array}{l}\text { Policy (Tables 14- } \\
\text { 20) }\end{array}$ & 3.2320 & 3.0381 & 2.9563 & .20 & .104 & .185 \\
\hline $\begin{array}{l}\text { Programme: Pro- } \\
\text { posal (Table 21) }\end{array}$ & 3.3415 & 3.3077 & 3.0833 & .33 & .395 & .452 \\
\hline $\begin{array}{l}\text { Programme: Exam- } \\
\text { ination (Table 22) }\end{array}$ & 2.4737 & 2.2500 & 2.3333 & .55 & .620 & .754 \\
\hline $\begin{array}{l}\text { People: Supervisor } \\
\text { (Table 23) }\end{array}$ & 3.1707 & 3.1429 & 2.9091 & .62 & .539 & .531 \\
\hline $\begin{array}{l}\text { People: Candidate } \\
\text { (Table 24) }\end{array}$ & 3.6585 & 3.6429 & 3.5455 & .27 & .815 & .740 \\
\hline $\begin{array}{l}\text { People: Examiner } \\
\text { (Table 25) }\end{array}$ & 3.1000 & 2.3846 & 2.4167 & .64 & .004 & .007 \\
\hline
\end{tabular}

The second analysis performed a Spearman's rank order correlation between latent variables and ordered biographic variables of respondents. A medium correlation of $.217(\mathrm{p}=0.080)$ was observed which indicates that the longer members serve on higher degree committees, the more they agree with the survey item: 'The quality of the doctorate awarded depends on the disciplinary knowledge of the supervisor'. No statistical significant correlations were indicated when compared with the respondents' other biographical information: number of years involved with doctoral supervision (Table 2), number of doctoral candidates currently being supervised (Table 3 ), and number of doctoral candidates supervised (Table 4).

\section{Summary of the Main Results}

Next, we discuss the main results that address the first research question: what is the state of higher degree committee members' perceptions of quality assurance of doctoral education at their respective universities? Firstly, the respondents indicated that quality assurance lies on the meso level (institutional) more than on the macro (national). They also agreed that quality assurance measures improve doctoral education. Respondents at the traditional universities were the only ones who strongly supported the view that quality could be assured more efficiently if potential theoretical, methodological, and contextual contributions were all included in the doctoral candidate's research proposal. It, as well as further research on the topic (Simmonds \& Du Preez, 2014), advocates that more emphasis be placed on the theoretical, methodological, and contextual contributions made by doctoral studies. These suggestions and the responses given in this present study raise a number of interlinked questions, which will be addressed below.

Secondly, a higher percentage of respondents indicated that they saw quality assurance through supervision as more important than the institution that awards the degree as being a marker for quality assurance. In particular, the results indicated that the longer members serve on higher degree committees, the more they agree that the quality of the doctorate depends on the disciplinary knowledge of the supervisor. This strong emphasis on the autonomy of the individual supervisor might be a reaction to an over-emphasis on quality assurance, particularly since it can be interpreted as a veiled attack on the integrity of the universities (Collini, 2012, p. 108). 
Thirdly, national and international positionality refers to both the standing and ranking of universities and the positionality of the candidate's work in terms of its main contributions. Higher de-

gree committee members at traditional universities saw the appointment of examiners as a prominent quality measure. In addition, many of the respondents agreed that doctoral candidates' contributions to the scholarly and public domain promote quality assurance in the doctoral education process. However, only a low percentage of respondents deemed a contribution to the market domain as linked to quality assurance. It seems that respondents at traditional universities see their doctorates as shifting the frontiers of their disciplines more than those at the other types of universities.

\section{Problematising the Main Results Using Academic Freedom Amidst Mode 3 Knowledge Production as a Lens}

When the main results are problematised using academic freedom and mode 3 knowledge production as a lens, alternative hypothetical questions that could inform future research are disclosed. These alternative hypothetical questions emanated from the second research question: what hypothetical questions that arise could inform future research when the main results are problematised using academic freedom amidst mode 3 knowledge production as a lens? Firstly, why do members of higher degrees committees attach more value to quality assurance on institutional level amidst the rising call for quality assurance to be benchmarked internationally? Secondly, what epistemological shifts underpin the debate on the theoretical, methodological, and contextual contributions of doctoral candidates? Thirdly, (linked to the previous question), we wish to question why few respondents believed that it is necessary for doctoral candidates to contribute to the scholarly and public domains, but not to the market domain (private sector)? This question is particularly important in the context of the heightened emphasis on the commercialisation of knowledge in higher education institutions. Each of these questions could be explored in future research. What we present next, are merely tentative directions to a "path [that] constantly twists back on itself, so the direction it faces at one stage is a virtually worthless clue to the direction in which the eventual solution lies; but, as in a maze, the only way of reaching the centre [...] is to advance along that twisting path" (Dummett as cited in Green, 2012, p. 9).

With regard to the first question, we suspect that members of higher degree committees attach more value to quality assurance on the meso level (institutional) as a way of protecting academic freedom and institutional autonomy in the face of a global trend towards benchmarking. In the light of our earlier plea towards an alternative approach to such a seemingly conflicting position, it becomes necessary to ask how a healthy, constructive contention between academic freedom and quality assurance could be cultivated.

This brings us to the second and third questions that allude to the changing conceptions of knowledge production theories, especially mode 3 knowledge production. The theories of knowledge production require doctoral quality assurance to be measured not only as contributions to knowledge and methodology, but as contributing to the global knowledge society through its contextual contribution (cf., Simmonds \& Du Preez, 2014). The questions that arise are whether a demand for such contributions threatens academic freedom and why respondents overall felt that contributions to industry and business domains are less important than contributions to the other two areas. This might be a silent revolt against the proliferation of discourses about social responsiveness and democratic participation with government, industry, and civil society that accompany discourses of knowledge production and academic freedom. In this regard, Lategan (2009, pp. 62-63) argues that state regulation and interference infringe academic freedom by navigating its intellectual capabilities towards enterprise. Le Grange (2009, p. 107) argues that a false academic 
freedom is advocated under the banner of self-regulation as proposed by modes 2 (and 3 ) knowledge production which results in government steering academia from a distance. For us, the following question should be addressed: "How should curricula [doctoral education] reflect the intricate relationship between institutional autonomy, academic freedom and public accountability?" (Bitzer, 2011, p. 47). This question is particularly important given the tendency for modes of knowledge production to result in a tension and conflict between academic freedom (autonomy) and social responsiveness (accountability) (Albertyn \& Daniels, 2009, p. 412). In line with the alternative position we opt for, the question then becomes: how could different universities and national bodies engage in a dialogue to foster a healthy, constructive contention between academic freedom and quality assurance?

This brings us to our last argument that is concerned with how doctoral education should ideally be constituted given the core expectation of new knowledge generation in a culture of academic freedom. The respondents attached considerable value to doctoral education as a component of quality assurance of the doctoral process, especially in the proposal and examination phases. What seems to be necessary is quality doctoral education that emphasises a doctoral candidate's responsibility to contribute to various modes of knowledge production and, in the process, to preserve academic freedom. This is only possible if quality assurance of doctoral education and academic freedom are not perceived as mutually exclusive and/or conflicting terms, but as symbiotic notions that could be nurtured through healthy dialogues between universities and national bodies.

\section{Conclusion}

Members of higher degree committees at public institutions offering doctoral degrees in Education have revealed how South Africa is assuring quality for doctorates in this field. The main results have been problematised using academic freedom amidst mode 3 knowledge production as a lens. This gave rise to several hypothetical questions that could be explored in future research. Higher education is becoming increasingly dependent on external bodies that govern their core business (including quality assurance of doctoral education) as a result of the shifting frontiers of knowledge production. Instead of arguing that academic freedom might be in jeopardy because of increasing attention given to quality assurance, one could argue for a constructive contention between quality assurance as regulation and academic freedom. Apart from the future research questions that we identified, the ultimate challenge and matter that could be addressed in future research would be the creation of enabling spaces where dialogues between universities and national bodies could transpire so that ongoing quality assurance derives from academic freedom.

\section{Acknowledgement}

This work is based on a research project supported by the National Research Foundation (NRF) of South Africa (Grant Number ERSA13110557428). The grant holder acknowledges that opinions, findings, and conclusions or recommendations expressed in any publication generated by the NRF-supported research are those of the author(s), and that the NRF accepts no liability whatsoever in this regard. We would also like to acknowledge the statistician, Dr Suria Ellis, who assisted us in compiling the survey and determining the sample as well as analysing and interpreting the survey results. Finally, the reviewers of the article must also be commended for their valuable insights and constructive engagements with the article. 


\section{References}

Albertyn, R., \& Daniels, P. (2009). Research within the context of community engagement. In E. Bitzer (Ed.), Higher education in South Africa: A scholarly look behind the scenes. Stellenbosch: SUN Press.

Academy of Science for South Africa (ASSAf). (2010). The PhD study: An evidence based study on how to meet the demands for high level skills in an emerging economy, Consensus Report. Pretoria: ASSAf.

Beets, P. (2009). Towards integrated assessment in South African higher education. In E. Bitzer (Ed.), Higher education in South Africa: A scholarly look behind the scenes. Stellenbosch: SUN Press.

Bitzer, E. (2011). Inquiring the curriculum in higher education - A limited (South African) perspective. In E. Bitzer \& N. Botha (Eds.), Curriculum inquiry in South African higher education. Stellenbosch: SUN Press.

Bless, C., Higson-Smith, C., \& Sithole, S. (2013). Fundamentals of social research methods: An African perspective. Cape Town: Juta.

Byrne, J., Jørgensen, T., \& Lukkola, T. (2013). Quality assurance in doctoral education - Results of the $A R D E$ project. Belgium: European University Association Publications.

Carayannis, E. G., \&Campbell, D. F. J. (2012). Mode 3 knowledge production in quadruple helix innovation systems: Twenty-first-century democracy, innovation, and entrepreneurship for development. New York: Springer.

Cloete, N. (2011). South Africa: Radical new plan for higher education. University World News, 4 December 2011. Retrieved 19 November 2013 from www.universityworldnews.com/article.php?story $=2011120222252975$

Cloete, N., Mouton, J., \& Sheppard, C. (2015). Doctoral education in South Africa: Policy, discourse and data. Cape Town: African Minds.

Cole, J. R. (2015). Academic freedom under fire. In. A. Bilgrami \& J. R. Cole (Eds.), Who's afraid of academic freedom? New York: Columbia University Press.

Collini, S. (2012). What are universities for? London: Penguin.

Department of Higher Education and Training (DHET). (2013). Higher education management information system (HEMIS) 2000-2012. Pretoria: Department of Higher Education and Training.

Du Preez, P. (2014). Education research for quality PhD study curriculum-making: A South African metastudy. 2014-2016. Research proposal submitted and proved by the National Research Foundation (NRF).

Du Preez, P., \& Simmonds, S. (2014). Curriculum, curriculum development, curriculum studies? Problematising theoretical ambiguities in doctoral theses in the education field. South African Journal of Education, 34(2), 1-14.

Grant, B. M. (2011). The bothersome business of curriculum in doctoral education. In E. Bitzer \& N. Botha (Eds.), Curriculum inquiry in South African higher education. Stellenbosch: SUN Press.

Green, K. (2012). Michael Dummett. The Philosophers' Magazine, Issue 57(2nd Quarter), 9-10.

Hay, D., \& Marais, N. (2011). The university curriculum as institutional transformation. In E. Bitzer \& N. Botha (Eds.), Curriculum inquiry in South African higher education. Stellenbosch: SUN Press.

Hessels, L., \& Van Lente, H. (2008). Rethinking new knowledge production: A literature re view and a research agenda. Research Policy, 37, 740-760.

Houser, J. (2007). How many are enough? Statistical power analysis and sample size estimation in clinical research. Journal of Clinical Research Best Practices, 3(3), 1-5.

Jackson, C., \& Tinkler, P. (2001). Back to basics: A consideration of the purposes of the PhD viva. Assessment and Evaluation in Higher Education, 26(4), 355-366. 
Krause, K. (2012). Addressing the wicked problem of quality in higher education: Theoretical approaches and implications. Higher Education Research \& Development, 31(3), 285-297.

Lategan, L. (2009). The university as key concept in higher education studies: A journey with research into a conceptual analysis of a university. In E. Bitzer (Ed.), Higher education in South Africa: A scholarly look behind the scenes. Stellenbosch: SUN Press.

Le Grange, L. (2009). The university in a contemporary era: Reflections on epistemological shifts. In E. Bitzer (Ed.), Higher education in South Africa: A scholarly look behind the scenes. Stellenbosch: SUN Press.

Leshem, S., \& Trafford, V. (2007). Overlooking the conceptual framework. Innovations in Education and Teaching International, 44(1), 93-105.

Maree, K., \& Pietersen, J. (2007). The quantitative research process. In K. Maree (Ed.), First steps in research. Pretoria: Van Schaik Publishers.

Mouton, J. (2001). How to succeed in your master's \& doctoral studies: A South African guide and resource book. Pretoria: Van Schaik Publishers.

Pietersen, J., \& Maree, K. (2007). Standardisation of a questionnaire. In K. Maree (Ed.), First steps in research. Pretoria: Van Schaik Publishers.

Punch, K. F. (2006). Developing effective research proposals. Los Angeles \& London: Sage.

Shaw, M., \& Green, D. H. (2002). Benchmarking the PhD - A tentative beginning. Quality Assurance in Education, 10(2), 116-124.

Simmonds, S., \& Du Preez, P. (2014). The centrality of the research question for locating PhD studies in the global knowledge society. South African Journal of Higher Education, 28(5), 1606-1623.

Sinclair, M. (2004). The pedagogy of 'good' PhD supervision: A national cross-disciplinary investigation of PhD supervision. Australian Government: Department of Education, Science and Training.

South Africa. (2011). National development plan: Vision for 2030. Retrieved 4 April 2016 from http://policyresearch.limpopo.gov.za/bitstream/handle/123456789/941/NDP\%20Vision\%202030.pdf?s equence $=1$

Stone, G. R. (2015). A brief history of academic freedom. In A. Bilgrami \& J. R. Cole (Eds.), Who's afraid of academic freedom?. New York: Columbia University Press.

Tinkler, P., \& Jackson, C. (2000). Examining the doctorate: Institutional policy and the $\mathrm{PhD}$ examination process in Britain. Studies in Higher Education, 25(2), 167-180. 


\section{Appendix}

\section{The Survey}

Thank you for your willingness to complete this survey, which forms part of an NRF project entitled 'Education research for quality doctoral study curriculum-making: a South African meta-study' (project number ERSA13110557428). This survey will take approximately 20 minutes to complete. Please complete all the items in this survey, unless advised differently. The information will be treated confidentially and your identity will remain anonymous. This project has been approved by the grant holders institution, the North West University, under the following ethical number: (insert ethics number)

The purpose of this survey is to determine trends in national higher degrees committee members' understandings of what constitutes a quality doctoral proposal and examination process.

The overall aim of this research project is to develop curriculum strategies for the development, support and improvement of doctoral education with specific focus on proposal and examination processes and benchmarking these internationally.

Should you require further information about the project please contact Petro du Preez (petro.dupreez@nwu.ac.za).

I hereby consent to participate in this research study:

- Yes

- No

* If the participant says 'yes' then SurveyMonkey will continues onto the survey questions. If the participant indicates 'no' then SurveyMonkey does not continue.

BIOGRAPHICAL INFORMATION (These questions will be structured on SurveyMonkey in "tick the appropriate box" style.)

1. I am employed at the following university (include list of universities)

2. I've been part of a higher degrees committee at my institution for approximately: 1-3 years; 4-6 years; 7 and more years

3. I've been involved with doctoral supervision / management / education for approximately: 1-3 years; 4-6 years; 7 and more years

4. Number of doctoral candidates in your discipline that you are currently supervising or co-supervising at your or any other institution: 0 candidates; 1-5 candidates; 6-10 candidates; 11-20 candidates; 21-30 candidates; 30 and more candidates

5. Number of doctoral graduates that you have successfully supervised towards completion in your discipline during your career: 0 graduates; 1-5 graduates; 6-10 graduates; 11-20 graduates; 21-30 graduates; 30 and more graduates 


\section{SECTION A}

\begin{tabular}{|c|c|c|c|c|c|c|c|c|}
\hline \multicolumn{4}{|c|}{$\begin{array}{l}\text { The current situation on } \\
\text { doctoral quality based } \\
\text { on your personal insti- } \\
\text { tutional experience. }\end{array}$} & \multirow[b]{2}{*}{$\begin{array}{l}\text { ITEMS PERTAINING TO THE QUALITY OF } \\
\text { DOCTORAL EDUCATION AND DEGREES } \\
\text { AWARDED IN SOUTH AFRICA }\end{array}$} & \multicolumn{4}{|c|}{$\begin{array}{l}\text { What you think the cur- } \\
\text { rent situation on doc- } \\
\text { toral quality at other } \\
\text { public South African } \\
\text { institutions is. }\end{array}$} \\
\hline 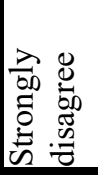 &  & 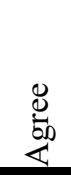 &  & & 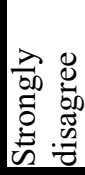 & 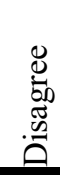 & 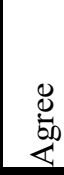 & 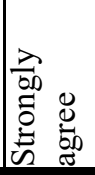 \\
\hline 1 & 2 & 3 & 4 & $\begin{array}{l}\text { Doctorates demonstrate high-level research that } \\
\text { shifts the frontiers of their disciplines. }\end{array}$ & 1 & 2 & 3 & 4 \\
\hline 1 & 2 & 3 & 4 & $\begin{array}{l}\text { Accreditation of doctoral qualifications by the High- } \\
\text { er Education Qualifications Committee assures quali- } \\
\text { ty. }\end{array}$ & 1 & 2 & 3 & 4 \\
\hline 1 & 2 & 3 & 4 & $\begin{array}{l}\text { The current national standards to assess the quality of } \\
\text { doctorate outputs in South Africa are clear. }\end{array}$ & 1 & 2 & 3 & 4 \\
\hline 1 & 2 & 3 & 4 & $\begin{array}{l}\text { Quality assurance on the doctoral level is a matter of } \\
\text { institutional accountability. }\end{array}$ & 1 & 2 & 3 & 4 \\
\hline 1 & 2 & 3 & 4 & $\begin{array}{l}\text { Quality assurance on the doctoral level is aimed to } \\
\text { improve the quality of doctoral education. }\end{array}$ & 1 & 2 & 3 & 4 \\
\hline 1 & 2 & 3 & 4 & $\begin{array}{l}\text { Quality assurance on the doctoral level is aimed to } \\
\text { improve the quality of supervision. }\end{array}$ & 1 & 2 & 3 & 4 \\
\hline 1 & 2 & 3 & 4 & $\begin{array}{l}\text { Universities promote a 'quality culture' regarding } \\
\text { doctoral education rather than simply putting quality } \\
\text { assurance processes in place. }\end{array}$ & 1 & 2 & 3 & 4 \\
\hline 1 & 2 & 3 & 4 & $\begin{array}{l}\text { Quality assurance of doctoral studies starts with the } \\
\text { quality of a research proposal. }\end{array}$ & 1 & 2 & 3 & 4 \\
\hline 1 & 2 & 3 & 4 & $\begin{array}{l}\text { Quality assurance of doctoral studies depends on the } \\
\text { quality of supervision provided. }\end{array}$ & 1 & 2 & 3 & 4 \\
\hline 1 & 2 & 3 & 4 & $\begin{array}{l}\text { The quality of the doctorate awarded depends on the } \\
\text { reputation of the awarding institution. }\end{array}$ & 1 & 2 & 3 & 4 \\
\hline 1 & 2 & 3 & 4 & $\begin{array}{l}\text { The quality of the doctorate awarded depends on the } \\
\text { supervisory experience of a supervisor. }\end{array}$ & 1 & 2 & 3 & 4 \\
\hline 1 & 2 & 3 & 4 & $\begin{array}{l}\text { The quality of the doctorate awarded depends on the } \\
\text { disciplinary knowledge of a supervisor. }\end{array}$ & 1 & 2 & 3 & 4 \\
\hline 1 & 2 & 3 & 4 & $\begin{array}{l}\text { The quality of the doctorate awarded depends on the } \\
\text { nature of the examination process. }\end{array}$ & 1 & 2 & 3 & 4 \\
\hline 1 & 2 & 3 & 4 & $\begin{array}{l}\text { The quality of the doctorate awarded depends on the } \\
\text { scientific publications that arose from the research. }\end{array}$ & 1 & 2 & 3 & 4 \\
\hline 1 & 2 & 3 & 4 & $\begin{array}{l}\text { The quality of the doctorate awarded depends on the } \\
\text { impact of the research on the community. }\end{array}$ & 1 & 2 & 3 & 4 \\
\hline 1 & 2 & 3 & 4 & $\begin{array}{l}\text { The quality of the doctorate awarded depends on the } \\
\text { extent to which it contributed to innovation in the }\end{array}$ & 1 & 2 & 3 & 4 \\
\hline
\end{tabular}




\begin{tabular}{|c|c|c|c|c|c|c|c|c|}
\hline & & & & private sector. & & & & \\
\hline 1 & 2 & 3 & 4 & $\begin{array}{l}\text { Quality assurance of doctoral studies depends on the } \\
\text { level of internationalisation at the institution. }\end{array}$ & 1 & 2 & 3 & 4 \\
\hline 1 & 2 & 3 & 4 & $\begin{array}{l}\text { The quality of the doctorate awarded depends on the } \\
\text { duration of the candidate's enrolment for the degree. }\end{array}$ & 1 & 2 & 3 & 4 \\
\hline 1 & 2 & 3 & 4 & $\begin{array}{l}\text { The quality of the doctorate awarded depends on the } \\
\text { candidate's engagement with the study. }\end{array}$ & 1 & 2 & 3 & 4 \\
\hline
\end{tabular}

Any comments regarding quality of doctoral education at your institution or at other institutions: An open-ended question on SurveyMonkey for respondents to answer if they wish to do so.

\section{SECTION B}

FILTER QUESTION: Do doctoral candidates at your institution present a research proposal to a committee for approval?

Yes - answer both Likert scale columns (will be organised on SurveyMonkey as such)

No - only answer second Likert scale column (will be organised on SurveyMonkey as such)

\section{The current situation on doctoral quality based on your personal institu- tional experience.}

\begin{tabular}{|l|l|l|l|l}
\hline & & & $\begin{array}{l}\text { ITEMS PERTAINING TO DOCTORAL PRO- } \\
\text { POSAL WRITING AND THE ASSESSMENT } \\
\text { OF PROPOSALS }\end{array}$ \\
\hline 1 & 2 & 3 & 4 & $\begin{array}{l}\text { Formal training of doctoral candidates in proposal } \\
\text { writing assists in the overall quality of a study. }\end{array}$ \\
\hline 1 & 2 & 3 & 4 & $\begin{array}{l}\text { Proposals are assessed by a committee to determine } \\
\text { whether a potential methodological contribution } \\
\text { will be made in the study. }\end{array}$ \\
\hline 1 & 2 & 3 & 4 & $\begin{array}{l}\text { Proposals are assessed by a committee to determine } \\
\text { whether a potential theoretical contribution will be } \\
\text { made in the study. }\end{array}$ \\
\hline 1 & 2 & 3 & 4 & $\begin{array}{l}\text { Proposals are assessed by a committee to determine } \\
\text { whether a potential contextual contribution will be } \\
\text { made through the study. }\end{array}$ \\
\hline 1 & 2 & 3 & 4 & $\begin{array}{l}\text { Proposals are assessed by a committee to determine } \\
\text { whether the supervisor is qualified to supervise a } \\
\text { study. }\end{array}$ \\
\hline whether the supervisor is equipped to supervise a \\
\hline study.
\end{tabular}

What you think the current situation on doctoral quality at other public South African institutions is.

\begin{tabular}{|c|c|c|c|}
\hline 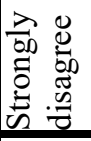 & 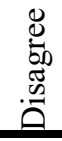 & 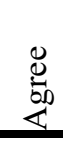 & 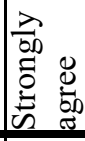 \\
\hline 1 & 2 & 3 & 4 \\
\hline 1 & 2 & 3 & 4 \\
\hline 1 & 2 & 3 & 4 \\
\hline 1 & 2 & 3 & 4 \\
\hline 1 & 2 & 3 & 4 \\
\hline 1 & 2 & 3 & 4 \\
\hline
\end{tabular}

Any comments regarding doctoral proposal writing and the assessment of proposals at your institution or at other institutions:

An open-ended question on SurveyMonkey for respondents to answer if they wish to do so. 


\section{$\underline{\text { SECTION C }}$}

\begin{tabular}{|c|c|c|c|c|c|c|c|c|}
\hline \multicolumn{4}{|c|}{$\begin{array}{l}\text { The current situa- } \\
\text { tion on doctoral } \\
\text { quality based on } \\
\text { your personal insti- } \\
\text { tutional experience. }\end{array}$} & \multirow[b]{2}{*}{$\begin{array}{l}\text { ITEMS PERTAINING TO THE DOCTORAL } \\
\text { EXAMINATION PROCESSES }\end{array}$} & \multicolumn{4}{|c|}{$\begin{array}{l}\text { What you think the } \\
\text { current situation on } \\
\text { doctoral quality at } \\
\text { other public South } \\
\text { African institutions } \\
\text { is. }\end{array}$} \\
\hline 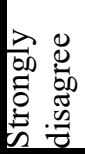 & 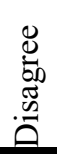 & $\underset{\mathscr{E}}{\gtrless}$ & 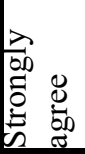 & & 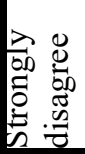 &  & 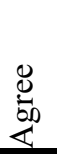 & 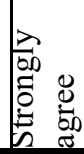 \\
\hline 1 & 2 & 3 & 4 & $\begin{array}{l}\text { The quality of the doctorate awarded depends on the exam- } \\
\text { iners appointed to assess the thesis / dissertation. }\end{array}$ & 1 & 2 & 3 & 4 \\
\hline 1 & 2 & 3 & 4 & $\begin{array}{l}\text { The appointment of international examiners for the assess- } \\
\text { ment of a doctoral dissertation / thesis contributes to the } \\
\text { quality thereof. }\end{array}$ & 1 & 2 & 3 & 4 \\
\hline 1 & 2 & 3 & 4 & $\begin{array}{l}\text { The assessment form / guidelines used to assess a doctoral } \\
\text { dissertation / thesis contributes to the quality of the examina- } \\
\text { tion process. }\end{array}$ & 1 & 2 & 3 & 4 \\
\hline 1 & 2 & 3 & 4 & $\begin{array}{l}\text { An oral defense of a doctoral dissertation / thesis contributes } \\
\text { to the quality of the examination process. }\end{array}$ & 1 & 2 & 3 & 4 \\
\hline 1 & 2 & 3 & 4 & $\begin{array}{l}\text { Doctoral candidates receive formal training to prepare them } \\
\text { for the examination process. }\end{array}$ & 1 & 2 & 3 & 4 \\
\hline
\end{tabular}

Any comments regarding doctoral examination processes at your institution or at other institutions: An open-ended question on SurveyMonkey for respondents to answer if they wish to do so.

\section{SECTION D}

CONCLUDING OPEN-ENDED QUESTION: Did you find that this questionnaire adequately covered the relevant issues? (Yes / No, if no, please identify additional issues which you would have liked to have seen covered.) An open-ended question on SurveyMonkey for respondents to answer if they wish to do so.

\section{Biographies}

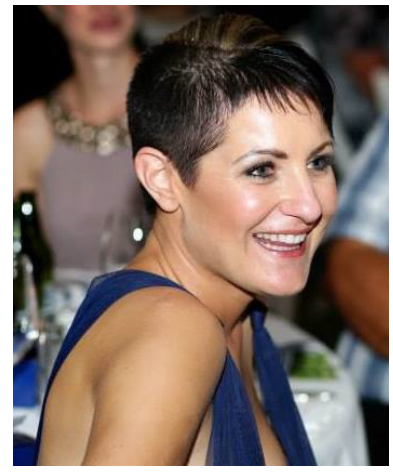

Petro du Preez is an Associate Professor in Curriculum Studies at the North-West University (Potchefstroom). Her research focuses on Curriculum Studies, Higher Education and Human Rights. Petro has successfully supervised 9 Masters and Doctoral students and currently supervises another 7 students. Her NRF funded research project is entitled, Education research for quality doctoral study curriculum-making: a South African meta-study. Petro is also the Editor-in-Chief of a new journal, Transformation in Higher Education. 


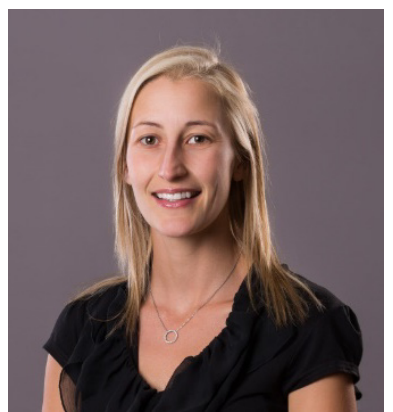

Shan Simmonds is a Senior Lecturer in Curriculum Studies at the North-West University (Potchefstroom Campus) and a member of the Edu-HRight research unit (Education and Human Rights in Diversity). She graduated with her PhD in 2013 from the North-West University after completing some of her PhD studies at the Vrije University, Amsterdam as part of the SAVUSA (South Africa Vrije University Strategic Alliance) scholarship that she received in 2012. Since 2013 she has supervised 4 Masters students, with 4 Masters and Doctoral in process. Shan's areas of research are Higher Education, Curriculum Studies, and Human Rights Education. 